\title{
Chlorido and bromido Oxaliplatin analogues as potential agents for CRC treatment: solution behavior, protein binding and cytotoxicity evaluation
}

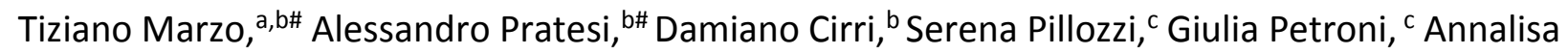
Guerri, ${ }^{\mathrm{b}}$ Annarosa Arcangelic Luigi Messori, ${ }^{\mathrm{b} *}$ Chiara Gabbiani ${ }^{\mathrm{a} *}$

aDepartment of Chemistry and Industrial Chemistry, University of Pisa, via Moruzzi, 13, 56124 Pisa,(Italy);

${ }^{b}$ Laboratory of Metals in Medicine (MetMed), Department of Chemistry, University of Florence, Via della Lastruccia 3, 50019, Sesto Fiorentino, (Italy);

${ }^{\mathrm{c}}$ Department of Experimental and Clinical Medicine, University of Florence, Viale GB Morgagni 50, 50134, Firenze, (Italy).

\#These two authors equally contributed

Despite the widespread use of platinum drugs in the treatment of colorectal cancer (CRC), due to the heavy side effects and to intrinsic or acquired Pt resistance, new and more efficient drugs are urgently needed. Starting from the encouraging results obtained for the complex $\mathrm{PtI}_{2}(\mathrm{DACH})$, we summarise here our recent advances, reporting data on the synthesis, on the chemical and biological features of two oxaliplatin analogues i.e. $\mathrm{PtBr}_{2}(\mathrm{DACH})$ and $\mathrm{PtCl}_{2}(\mathrm{DACH})$. The comparative approach of these studies reveals how these analogues possess interesting and differential pharmacological properties as well as some peculiar features that may be conveniently exploited to shed light in the mechanistic aspects involved in the pharmacological action of the parent drug. Furthermore, these findings are suitable for the design of more effective Pt-based anticancer drugs to be used in CRC treatment.

Keywords colorectal cancer, chemotherapy, oxaliplatin analogues, protein interaction, DNA interaction 


\section{Introduction}

Colorectal cancer (CRC) is one of the most common cause of death for cancer worldwide. ${ }^{1}$ Chemotherapy for CRC mainly relies on fluoropyrimidine compounds combined with platinum drugs, mainly cisplatin and its analogues carboplatin and oxaliplatin, being this latter the leading Ptbased drug for the treatment of this pathology. ${ }^{2}$ Oxaliplatin (Eloxatin ${ }^{\mathrm{TM}}$ ) is a third-generation platinum compound approved by United States Food and Drug Administration (FDA) on 2002 for the treatment of advanced CRC. To date thousands of patients worldwide have been treated with oxaliplatin, especially in combination with other drugs. ${ }^{3}$ Indeed, either the FOLFOX (5-FU, leucovorin, and oxaliplatin) or CapeOx (capecitabine and oxaliplatin) regimens are used most often. ${ }^{4}$ Nevertheless, serious drawbacks, such as a high systemic toxicity and platinum resistance are, still nowadays, relevant problems causing in some cases treatment failure. In recent times, we started to reconsider more systematically a series of clinically established Pt-based drugs analogues with unconventional ligands. In this view, we published some papers dealing with the chemical and biological features of cisplatin analogues where, the chlorido ligands were replaced by iodide and bromide ones. Interestingly, these modification lead to a modulation of chemical and biological profiles that substantially differ from those of the parent complex. ${ }^{5}$

In this frame, worthy of particular consideration is the ability of the iodide analogue of cisplatin i.e. cis- $\mathrm{PtI}_{2}\left(\mathrm{NH}_{3}\right)_{2}$ - to overcome platinum resistance in $\mathrm{CRC}$ cell lines. This finding prompted us to further expand the panel of this family of compounds with unconventional ligands and, in analogy with cis- $\mathrm{PtI}_{2}\left(\mathrm{NH}_{3}\right)_{2}$ the iodide analogue of oxaliplatin i.e. $\{(1 \mathrm{R}, 2 \mathrm{R})$-cyclohexane-1,2diamine diiodidoplatinum(II), $\left(\mathrm{PtI}_{2}(\mathrm{DACH})\right.$ hereafter), where the oxalate ligand was replaced by iodides, was synthesized and characterized. ${ }^{6}$

$\mathrm{Ptl}_{2}$ (DACH) shown to possess a number of peculiar chemical and biological features that make it particularly attractive. Despite its solution behavior is characterized by a classical hydrolysis profile with halide release, yet, is scarcely reactive toward model proteins being instead highly reactive toward DNA ss oligonucleotides. Notably, we found $\mathrm{Ptl}_{2}(\mathrm{DACH})$ capable to induce cytotoxicity effects almost superimposable with those of oxaliplatin in representative CRC cell lines being this latter feature accompanied to a higher proapoptotic effect than cisplatin and oxaliplatin. ${ }^{6}$ In light of these results, and in order to further expand the panel of oxaliplatin analogues, we decided to prepare and comparatively evaluate two other analogs of oxaliplatin bearing either chloride or bromide ligands in place of oxalate i.e. $\mathrm{PtCl}_{2}(\mathrm{DACH})$ and $\mathrm{PtBr}_{2}(\mathrm{DACH})$.

Importantly, both these two oxaliplatin derivatives, have been previously synthesized and extensively investigated as prospective antineoplastic agents either in vitro and in vivo on leukemia, ovarian or sarcoma models; yet, no information are available in literature regarding their possible application in the treatment of colorectal cancer. ${ }^{7,8 a}$

It may be stressed that, the presence of chloride or bromide ligands may lead to a selective modulation of important properties of these compounds, such as log P value and kinetic of ligands release, leading to a different biological and pharmacological properties. Also, the comparative analysis allows to correlate relevant chemical features with biological and pharmacological effects, that, in turn, allows to gain insights for the design of more effective complexes for CRC treatment. 


\section{Materials and Methods}

\section{Chemicals and reagents}

Chemicals have been purchased from Sigma-Aldrich and were used without further purification. Dodecameric oligonucleotide ODN2 (sequence CTACGGTTTCAC), lysozyme (HEWL) and RNase have also been purchased from Sigma-Aldrich.

\section{Chemistry}

\section{Synthesis of $\mathrm{PtCl}_{2}(\mathrm{DACH})$ and $\mathrm{PtBr}_{2}(\mathrm{DACH})$}

The two reported compounds were synthesized and purified according to literature procedures with slight modifications. ${ }^{8}$

\{(1R,2R)-cyclohexane-1,2-diamine\}dichloridoplatinum(II). $\mathrm{PtCl}_{2}$ (DACH) has been obtained starting from $99,7 \mathrm{mg}$ of $\mathrm{K}_{2} \mathrm{PtCl}_{4}\left(2.40 \times 10^{-4} \mathrm{~mol}\right)$ solubilised in $1.5 \mathrm{~mL}$ di of milli-Q water. 1,2diaminocyclohexane (1R,2R)-(-), DACH $\left(27.4 \mathrm{mg}, 2.42 \times 10^{-4} \mathrm{~mol}\right)$ was then solubilised in $2 \mathrm{~mL}$ of milli$\mathrm{Q}$ water and the obtained solution slowly added to $\mathrm{K}_{2} \mathrm{PtCl}_{4}$ water solution. After further four hours of stirring precipitate appeared, and complete precipitation of yellow crystals of $\mathrm{PtCl}_{2}(\mathrm{DACH})$ allowed over night at room temperature. The solid was then collected through vacuum filtration and washed with hot water and ice-cooled ethanol and ether. $88.36 \mathrm{mg}$ of $\mathrm{PtCl}_{2}(\mathrm{DACH})$ were obtained (yield $96 \%$ ). Complex was characterised through ${ }^{1} \mathrm{H}-\mathrm{NMR}$ and elemental analysis. ${ }^{1} \mathrm{HNMR}$ (DMF-d7, 400.13 MHz, $298 \mathrm{~K}): 2.45(\mathrm{t}, \mathrm{J}=8 \mathrm{~Hz}, 2 \mathrm{H}) ; 2.21(\mathrm{~d}, \mathrm{~J}=12 \mathrm{~Hz}, 2 \mathrm{H}) ; 1.52(\mathrm{~m}, 4 \mathrm{H}) ; 1.16(\mathrm{~m}$, $2 \mathrm{H}$ ). Elemental analysis of $\mathrm{C}, \mathrm{N}$ and $\mathrm{H}$ [calculated $\mathrm{C}: 18.96 \%, \mathrm{H}: 3.71 \%, \mathrm{~N}: 7.37 \%$, experimental: C: $18.84 \%, \mathrm{H}: 3.66 \%, \mathrm{~N}: 7.30 \%]$.

\{(1R,2R)-cyclohexane-1,2-diamine\}dibromidoplatinum(II). For the synthesis of $\mathrm{PtBr}_{2}(\mathrm{DACH}), 99.9$ $\mathrm{mg}$ of $\mathrm{K}_{2} \mathrm{PtCl}_{4}\left(2.41 \times 10^{-4} \mathrm{~mol}\right)$, have been solubilised in $1.5 \mathrm{~mL}$ di of milli-Q water. A water solution $(2 \mathrm{~mL})$ of $\mathrm{KBr}\left(117.7 \mathrm{mg}, 9.64 \times 10^{-4} \mathrm{~mol}\right)$ was added to $\mathrm{K}_{2} \mathrm{PtCl}_{4}$ and stirred $\left(50^{\circ} \mathrm{C}\right)$ in the dark for five minutes until quantitative conversion of $\mathrm{K}_{2} \mathrm{PtCl}_{4}$ in $\mathrm{K}_{2} \mathrm{PtBr}_{4}$ was obtained. 1,2-diaminocyclohexane $(1 \mathrm{R}, 2 \mathrm{R})-(-), \mathrm{DACH}\left(27.2 \mathrm{mg}, 2.41 \times 10^{-4} \mathrm{~mol}\right)$ was then solubilised in $2 \mathrm{~mL}$ of milli-Q water and the obtained solution slowly added to $\mathrm{K}_{2} \mathrm{PtBr}_{4}$ water solution. After further four hours of stirring precipitate appeared, and complete precipitation of yellow crystals of $\mathrm{PtBr}_{2}(\mathrm{DACH})$ allowed over night at room temperature. The solid was then collected through vacuum filtration and washed with hot water and ice-cooled ethanol and ether. $79.27 \mathrm{mg}$ of $\mathrm{PtBr}_{2}(\mathrm{DACH})$ were obtained (yield $70 \%$ ). Complex was characterised through ${ }^{1} \mathrm{H}-\mathrm{NMR}$ and elemental analysis. ${ }^{1} \mathrm{HNMR}$ (DMF-d7, $400.13 \mathrm{MHz}$, $298 \mathrm{~K}): 2.50(\mathrm{t}, \mathrm{J}=8 \mathrm{~Hz}, 2 \mathrm{H}) ; 2.23(\mathrm{~d}, \mathrm{~J}=12 \mathrm{~Hz}, 2 \mathrm{H}) ; 1.56(\mathrm{~m}, 4 \mathrm{H}) ; 1.15(\mathrm{~m}, 2 \mathrm{H})$. Elemental analysis of C, $\mathrm{N}$ and $\mathrm{H}$ [calculated C: $15.36 \%, \mathrm{H}: 3.01 \%, \mathrm{~N}: 5.97 \%$, experimental: C: $16.50 \%, \mathrm{H}: 3.14 \%, \mathrm{~N}: 6.30 \%$ ].<smiles>Cl[PH]1(Cl)N[C@H]2CCCC[C@H]2N1</smiles>

$\mathrm{PtCl}_{2}(\mathrm{DACH})(1)$

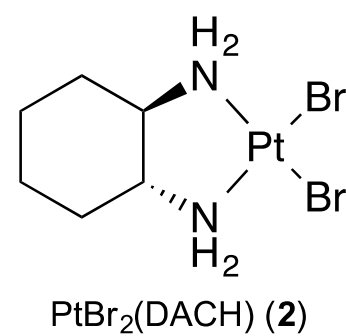

$\mathrm{PtBr}_{2}(\mathrm{DACH})(2)$

Figure 1. The two synthesized molecules. 


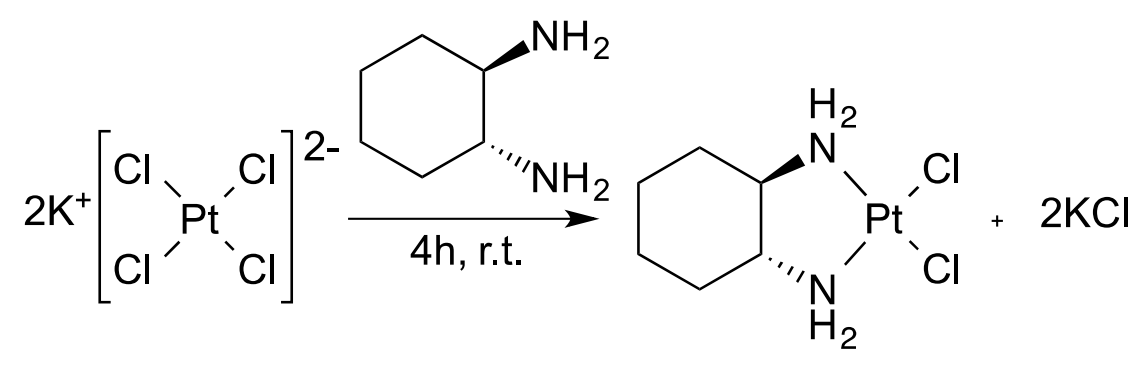

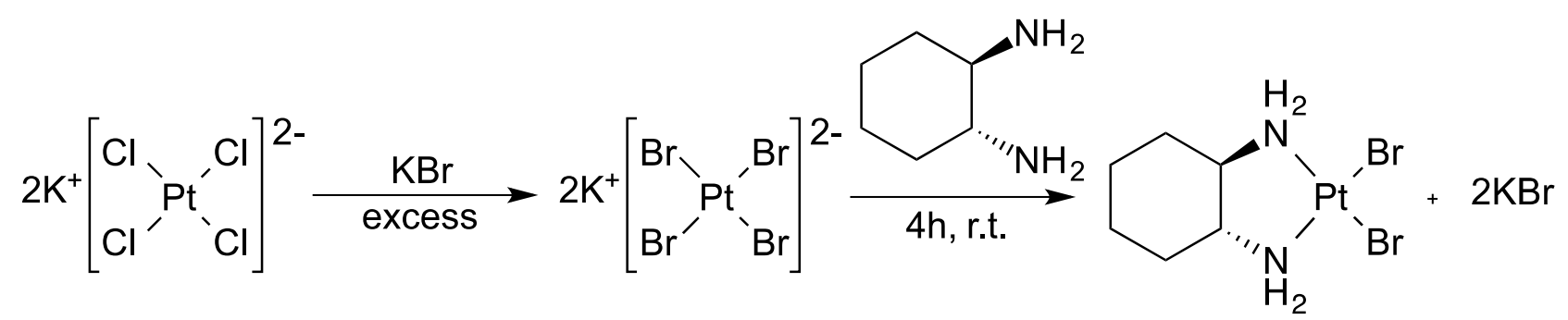

Scheme $\mathbf{1}$. Synthetic route for compounds 1 and $\mathbf{2}$, respectively.

\section{Uv-Vis experiments}

Solution behavior of $\mathrm{PtCl}_{2}(\mathrm{DACH})$ and $\mathrm{PtBr}_{2}(\mathrm{DACH})$ was assessed by spectrophotometric experiments performed with a Varian Cary 50 Bio UV-Vis spectrophotometer in the same condition used in our previous works. ${ }^{5 a, 6}$

\section{Log $P$ value determination}

The octanol-water partition coefficients for $\mathrm{PtCl}_{2}(\mathrm{DACH})$ and $\mathrm{PtBr}_{2}(\mathrm{DACH})$ was determined by modification of reported shake-flask method as reported in our previous work. ${ }^{6}$

\section{ESI-MS experiments}

For comparative purposes ESI-MS spectra of the ODN2-complexes and protein-complexes mixtures were recorded as already reported in literature. ${ }^{5 b, 6}$

\section{Cell culture}

Human colorectal cancer cell lines (HCT-116, HCT-8 and HT29) were cultured in RPMI-1640 medium (Euroclone; Milan, Italy), supplemented with $2 \%$ L-Glut and $10 \%$ fetal bovine serum (FBS) (complete medium). Human embryonic kidney HEK293 cell line was cultured in DMEM medium (Euroclone; Milan, Italy), supplemented with $2 \%$ L-Glut and $10 \%$ fetal bovine serum (FBS).

\section{Cell viability assay}

To evaluate the $I C_{50}$ of each compound, cell viability was assessed through the Trypan Blue exclusion test (Sigma-Aldrich). Cells were seeded at $1 \times 10^{4} /$ well in 96 -well plates (Costar Corning) in complete medium and incubated for $24 \mathrm{~h}$ before compound addiction. Following the addition, cells were further incubated for 24 hours. Cells were then harvested and counted by the Trypan Blue exclusion test using a hemocytometer. All experiments were performed in triplicate. The $\mathrm{IC}_{50}$ values were calculated for each cell line and data fitted using a Hill1-type equation by using Origin Software (Microcal Origin 8.0 software; OriginLab Corporation, Northampton, MA).

\section{Cell cycle analysis}

Cell cycle distribution was assessed by flow cytometry after staining the cells with propidium iodide (PI). Cells were seeded and treated generally with different compound at their $\mathrm{IC}_{50}$ for $24 \mathrm{~h}$ as already described.6 


\section{Results and Discussion}

\section{Synthesis and characterization of $\mathrm{PtCl}_{2}$ (DACH) and $\mathrm{PtBr}_{2}$ (DACH)}

The same synthetic route already exploited for the synthesis of $\mathrm{Ptl}_{2}(\mathrm{DACH})$, and based on modification of existing method ${ }^{6,9}$ was used, as reported in more detail in material and methods section. Both complexes were obtained in good yield and their purity assessed through $\mathrm{CHN}$ analysis, found to be higher than $95 \%$.

\section{Log $\mathbf{P}$ value determination}

Octanol-water partition coefficient is an important parameter giving important information related with the bioavailability and tendency of a compound to cross cell membranes. Through the modification of the classical flask-method and as already reported in our previous works, $5,7,10$ in line with the expectation we have determined for $\mathrm{PtCl}_{2}(\mathrm{DACH})$ and $\mathrm{PtBr}_{2}(\mathrm{DACH})$ a value respectively of $-0,47$ and $-0,16$. For comparison purposes log $P$ values for a few parent $P t$ complexes are also reported in table 2 .

Remarkably, in line with results obtained for cisplatin analogues, $5^{\mathrm{b}} \mathrm{PtBr}_{2}(\mathrm{DACH})$ manifests a larger lipophilic character than oxaliplatin and in less extent than $\mathrm{PtCl}_{2}(\mathrm{DACH})$, whereas shows a lower lipophilicity than $\mathrm{PtI}_{2}(\mathrm{DACH})$. It is well conceivable that this difference may have some appreciable effect in terms of pharmacological activity.

\begin{tabular}{lc}
\hline Compound & Log P \\
\hline Cisplatin & $-2,40^{*}$ \\
Oxaliplatin & $-1,58^{* *}$ \\
$\mathrm{Ptl}_{2}(\mathrm{DACH})$ & $0,76^{* *}$ \\
$\mathrm{PtCl}_{2}(\mathrm{DACH})$ & $-0,47$ \\
$\mathrm{PtBr}_{2}(\mathrm{DACH})$ & $-0,16$
\end{tabular}

Table 1. Determination of Log $\mathrm{P}$ for compound $\mathrm{PtCl}_{2}(\mathrm{DACH})$ and $\mathrm{PtBr}_{2}(\mathrm{DACH})$ compared with their iodide analogues, cisplatin and oxaliplatin. ${ }^{*}$ Ref. 5a; ${ }^{* *}$ Ref. 6.

\section{Solution behaviour}

The solution behaviour of $\mathrm{PtCl}_{2}(\mathrm{DACH})$ and $\mathrm{PtBr}_{2}(\mathrm{DACH})$ was studied spectrophotometrically under physiological-like conditions. Freshly prepared aqueous solutions of $\mathrm{PtCl} 2(\mathrm{DACH})$ and $\mathrm{PtBr} 2(\mathrm{DACH})$, in $50 \mathrm{mM}$ phosphate buffer, at $\mathrm{pH}=7.4$, manifest a bands in the UV-visible region, located at 320 $\mathrm{nm}$, that allow the continuous monitoring of the solution behaviour of this platinum complex (Figure 2).

After dissolution of the selected compounds in the reference buffer, progressive spectral changes are observed, consisting in a decrease of the band centered at $330 \mathrm{~nm}$ and the appearance of a new 
band around $280 \mathrm{~nm}$, tentatively assigned to a $d-d$ and a LMCT transition, respectively. ${ }^{5 b}$ These changes, probably are ascribed to the progressive release of the two halide ligands. ${ }^{5,6}$

The nature of the process and its kinetics are similar to what observed in the case of oxaliplatin despite release of halides in the case of $\mathrm{PtCl}_{2}(\mathrm{DACH})$ and $\mathrm{PtBr}_{2}(\mathrm{DACH})$ appears to be slightly faster than in case of oxaliplatin and $\mathrm{PtI}_{2}(\mathrm{DACH})$ (Figure 3, Table 2).
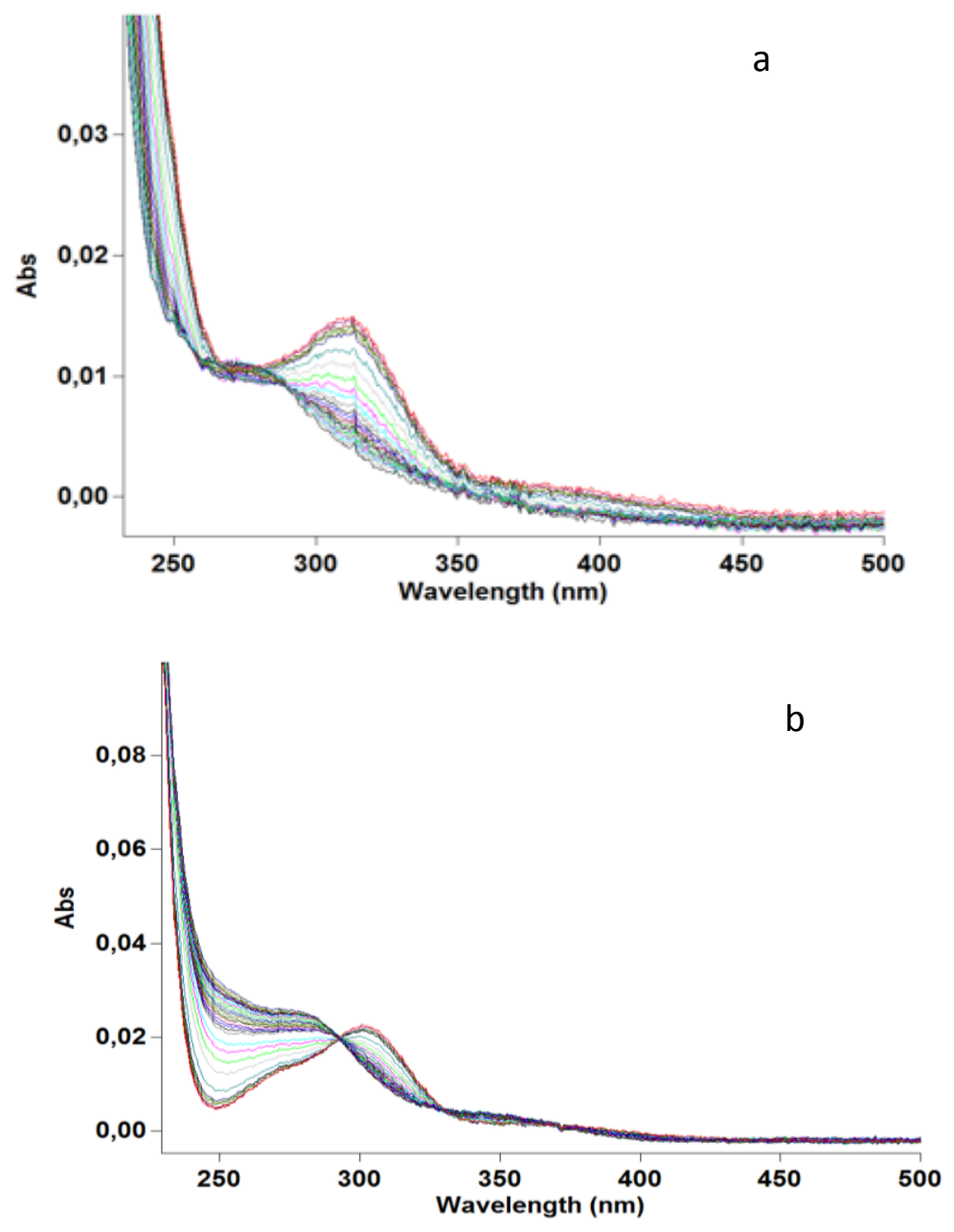

Figure 2. Time course spectra of (a) $\mathrm{PtCl}_{2}(\mathrm{DACH})$ and (b) $\mathrm{PtBr}_{2}(\mathrm{DACH}) 10^{-4} \mathrm{M}$ in $50 \mathrm{mM}$ phosphate buffer recorded over $72 \mathrm{~h}, \mathrm{RT}$. 

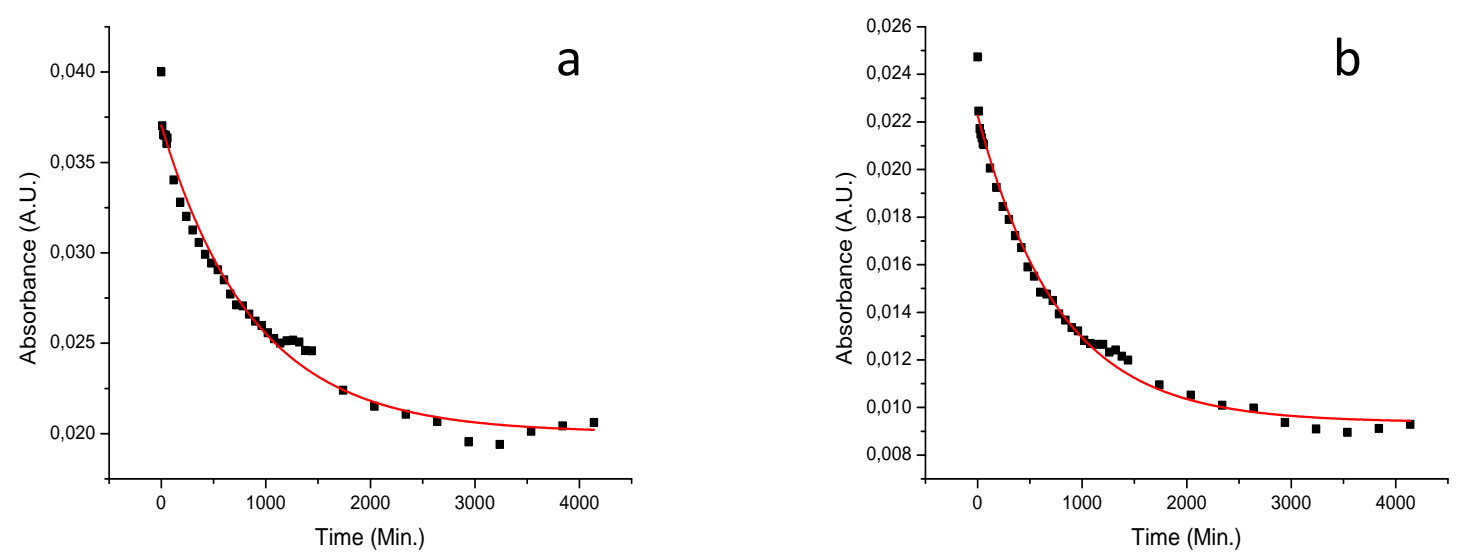

Figure 3. Experimental kinetic traces and calculated theoretical curve for the hydrolysis of the halido derivatives 1 (a) and $\mathbf{2}$ (b). kobs was calculated fitting with a single exponential function ( $\mathrm{pH}$ value=7.4).

\begin{tabular}{lll}
\hline Compound & $\boldsymbol{K}_{\text {obs }}\left(\mathbf{s}^{-1}\right)$ & $\boldsymbol{t}_{1 / 2}$ (min.) \\
\hline $\mathrm{PtCl}_{2}(\mathrm{DACH})$ & $1,89 \times 10^{-5}$ & 611,3 \\
$\mathrm{PtBr}_{2}$ (DACH) & $2,14 \times 10^{-5}$ & 538,4 \\
$\mathrm{PtI}_{2}(\mathrm{DACH}) *$ & $9,75 \times 10^{-6}$ & 1184,58 \\
Oxaliplatin* & $6,32 \times 10^{-6}$ & 1827,92
\end{tabular}

Table 2. Spectrophotometric determination of $\mathrm{K}_{o b s}$ and $t_{1 / 2}$ for the hydrolysis reaction of $\mathbf{1}$ and $\mathbf{2} 10^{-}$ ${ }^{4} \mathrm{M}$ in phosphate buffer over $72 \mathrm{~h}$. ${ }^{*}$ The $\mathrm{K}_{\text {obs }}$ reported have been previously determined in our laboratory. ${ }^{6}$ For oxaliplatin $K_{\text {obs }}$ was found to be close to that reported in literature by other authors. $^{11}$

\section{Interaction with model biomolecules, ESI-MS experiments}

To investigate the possible interactions occurring between chlorido and bromido oxaliplatin analogues and its potential biomolecular targets, the two complexes were incubated with two model proteins i.e. RNase (Figure 4) and hen egg white lysozyme (Figure S7) and possible adducts formation was investigated. These two proteins were chosen since their structures have been often used to characterize the interactions occurring between proteins and metallodrugs. These model proteins are well suitable for ESI-MS studies, offering a very important substrate for comparative mechanistic studies of metal-based drugs. We performed a few ESI-MS experiments where the selected complexes were incubated in $20 \mathrm{mM}$ ammonium acetate buffer, $\mathrm{pH}=6.8$ for increasing time intervals, from 24 to 72 hours. 


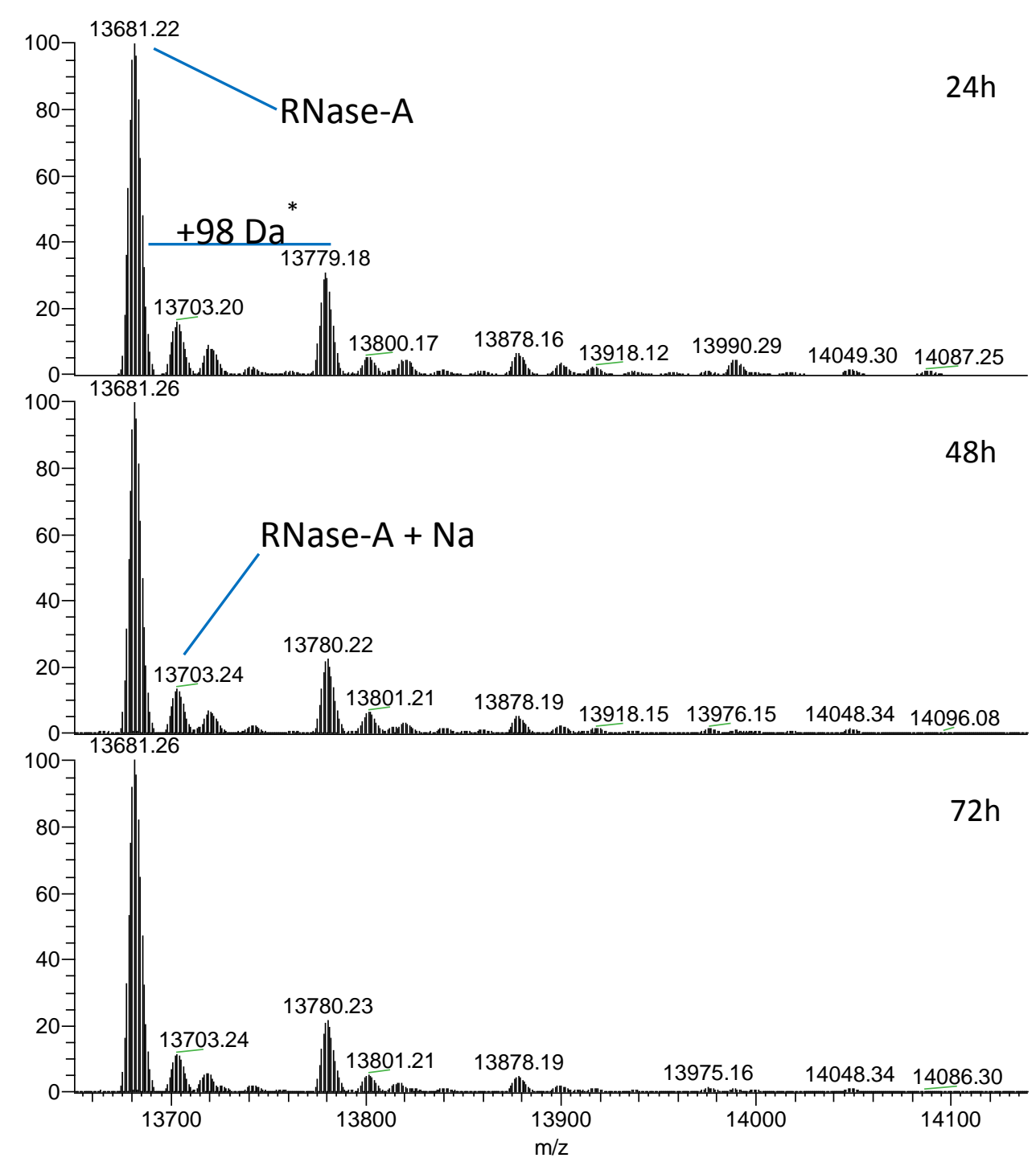

Figure 4. Deconvoluted ESI-MS spectra of RNase $A$ in $20 \mathrm{mM}$ ammonium acetate buffer, $\mathrm{pH}=6.8$ incubated with $\mathrm{PtBr}_{2}(\mathrm{DACH})$ after $24-72 \mathrm{~h}$ at $37^{\circ} \mathrm{C}$. The protein concentration was $10^{-4} \mathrm{M}$ (with complex to protein molar ratio of 3:1). *The saline buffer can contain small amount of phosphoric acid or sulphuric acid that are responsible of the formation of undesired and isobaric adducts with Ribonuclease A (+98 m/z). ${ }^{12}$

ESI-MS spectra recorded for RNase in presence of $\mathrm{PtBr}_{2}(\mathrm{DACH})$ did not showed any signal attributable to the metallated protein. The same results were obtained also for $\mathrm{PtCl}_{2}(\mathrm{DACH})$. This indicate that the two compounds are not able to bind this protein.

Also in the case of the ESI-MS spectra recorded for Lysozyme in presence of $\mathrm{PtBr}_{2}(\mathrm{DACH})$ or $\mathrm{PtCl}_{2}(\mathrm{DACH})$ did not showed any signal attributable to the metallated protein. In a previous study, similar results were obtained for $\mathrm{PtI}_{2}(\mathrm{DACH}) .{ }^{6}$ Conversely, in other works, some of us have shown significant interactions between oxaliplatin and the two selected model proteins. ${ }^{13,14}$ We hypothesized that an explanation for this difference in behaviour could be due to the fact that coordination of oxaliplatin to lysozyme and RNase implies a multi-step reaction at the level of aspartate residues. This implies, at first a non-covalent coordination of oxaliplatin to the protein; then detachment of one oxygen atom of oxalate from Pt coordination with a ring-opening step 
leading to monodentatate oxalate, with concomitant Pt coordination of the carboxylate group from an aspartate residue. Finally, the complete release of the oxalate ligand. ${ }^{9,10}$

The replacement of the oxalate with the halide ligands could cause loss of the first non-covalent interaction, which could be an important step in the reactivity of oxaliplatin with these proteins.

\section{Binding with model oligonucleotide: ESI-MS experiments}

It is generally accepted that the distortion of DNA generated upon binding of cisplatin and oxaliplatin is largely responsible for their antitumor properties.2,15

Subsequent drug activation via intracellular aquation reactions results in a variety of stable bifunctional DNA-platinum(II) adducts. 1,2-Intrastrand cross-links between two adjacent guanine bases $d(G G)$ or between an adenine and a guanine residue $d(A G)$ are primarily formed. The platinum centre of complexes, with a cis motif, preferentially coordinates to the N7 position of both adenine and guanine in the major groove of DNA. ${ }^{16}$ For these reasons we tested the binding properties of the three oxaliplatin analogues with a simplified oligonucleotide model bearing the characteristic GG motif.

The selected complexes interact extensively with the tested oligonucleotide bearing the GG motif (ODN2) through a classical reaction pattern involving preferential release of halide ligands (Figure 5). ${ }^{17} \mathrm{PtBr}_{2}(\mathrm{DACH})$, in this case, shows a greater reactivity compared to $\mathrm{PtCl}_{2}(\mathrm{DACH})$ and $\mathrm{PtI}_{2}(\mathrm{DACH})$, as highlights the ESI-MS spectrum in figure 5, in which the peak of native ODN2 completely disappeared after adduct formations.

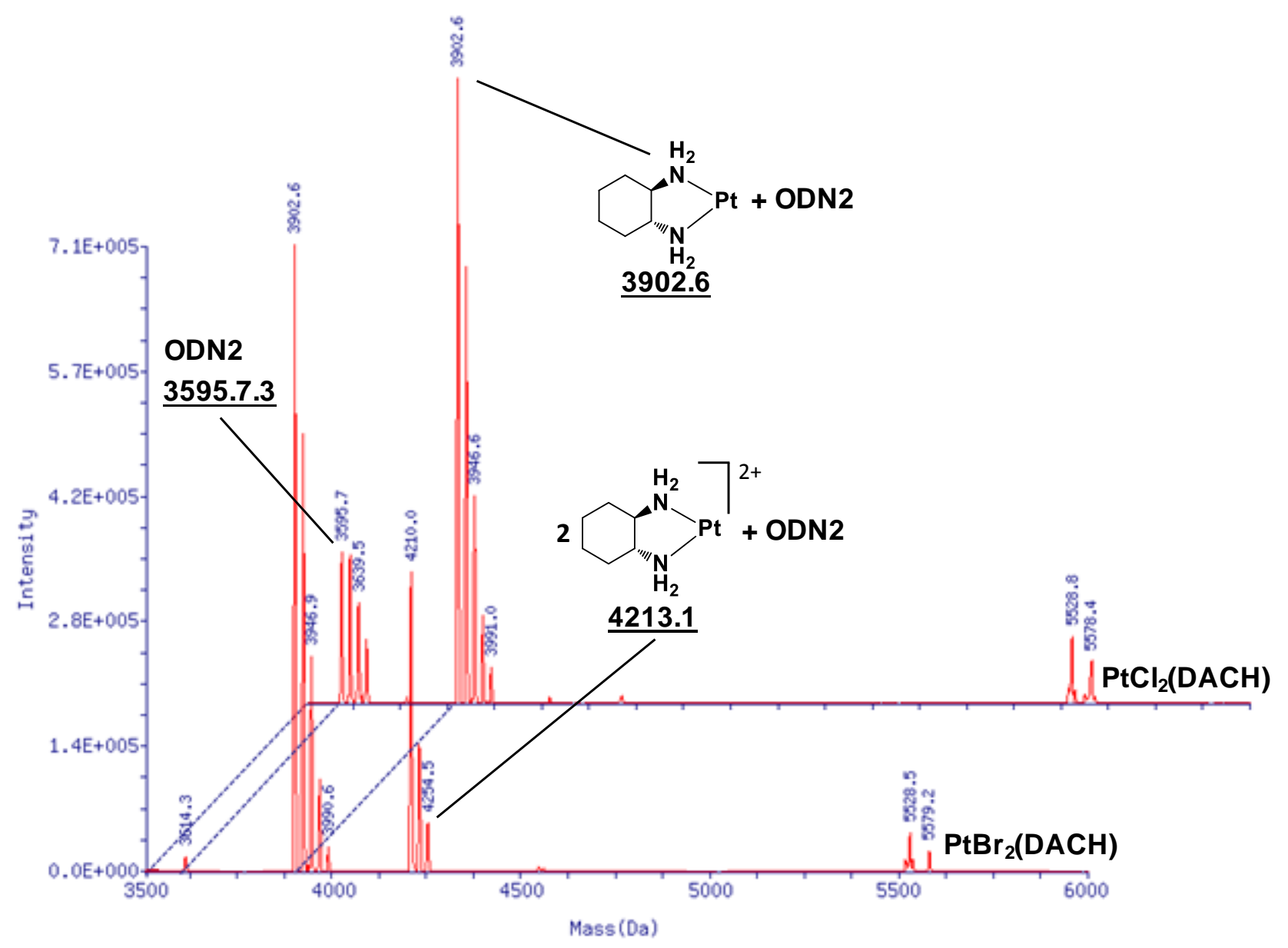


Figure 5. Deconvoluted ESI-MS spectra of ODN2 in Milli-Q water incubated with $\mathrm{PtCl}_{2}(\mathrm{DACH})$ and $\mathrm{PtBr}_{2}(\mathrm{DACH})$ after $72 \mathrm{~h}$ at $37^{\circ} \mathrm{C}$. The oligonucleotide concentration was $10^{-4} \mathrm{M}$ (with complex to oligonucleotide molar ratio of 2:1).

\begin{tabular}{lllll}
\hline & \multicolumn{3}{c}{ IC $_{50}$ value $(\mu \mathrm{M}$, mean \pm SEM) } \\
\cline { 2 - 5 } Cell lines & Cisplatin & Oxaliplatin & $\mathrm{PtCl}_{2}$ (DACH) & $\mathrm{PtBr}_{2}$ (DACH) \\
\hline HCT-116 & $24.4 \pm 0.6$ & $49.9 \pm 1.9$ & $9.86 \pm 1.4$ & $30.96 \pm 0.8$ \\
HT-29 & $16.7 \pm 2.3$ & $18.8 \pm 2.5$ & $49.07 \pm 1.1$ & $66.75 \pm 2.0$ \\
HCT-8 & $9.2 \pm 1.5$ & $33.1 \pm 0.6$ & $30.83 \pm 0.1$ & $48.64 \pm 0.1$ \\
HEK293 & $91.41 \pm 4.15$ & $>200$ & $194.86 \pm 6.8$ & $>200$
\end{tabular}

Table 3. $\mathrm{IC}_{50}(\mu \mathrm{M})$ of Cisplatin, Oxaliplatin, $\mathrm{PtCl}_{2}(\mathrm{DACH})$ and $\mathrm{PtBr}_{2}(\mathrm{DACH})$ in HCT-116, HT-29 and HCT8 CRC cell lines, as well as in an embryonic kidney cell line cell line (HEK 293). Cell viability was determined after 24 hours of treatment with the four different compounds (range 0-300 $\mu \mathrm{M}$ ), by the Trypan Blue exclusion test. $I C_{50}$ values (means \pm sem of three independent experiments) were calculated using the Origin Software (Microcal Origin 8.0 software; OriginLab Corporation, Northampton, MA) fitting experimental data with Hill1 type equation.

\section{Biological effects}

The cytotoxic effects of $\mathrm{PtCl}_{2}(\mathrm{DACH})$ and $\mathrm{PtBr}_{2}(\mathrm{DACH})$ were then investigated in three $\mathrm{CRC}$ cell lines (HCT-116, HCT-8 and HT-29) in comparison with cisplatin and oxaliplatin. A normal cell line (HEK 293 cells) was also included. Cells were exposed to increasing concentrations of the drugs for 24 hours, and the respective $\mathrm{IC}_{50}$ concentrations were determined by the Trypan blue exclusion test.

As reported in Table 3, $\mathrm{PtBr}_{2}(\mathrm{DACH})$ and in particular $\mathrm{PtCl}_{2}(\mathrm{DACH})$, in comparison to oxaliplatin shows a greater cytotoxic effect only on the cell line least sensitive to cisplatin (i.e. HCT-116) being less effective in the other cancer lines.

The $\mathrm{PtX}_{2}(\mathrm{DACH})$ series conserves appreciable cytotoxic properties and is roughly similar to oxaliplatin. This implies that replacement of oxalate with two halido ligands does not impair the cellular effects of this drug. Additionally, when evaluating the effects of all compounds on embryonic kidney cell line HEK293, we can assert that the cytotoxicity is overall similar and rather low, being the $\mathrm{PtCl}_{2}(\mathrm{DACH})$ significantly less cytotoxic.

Based on these results we studied the effects that $\mathrm{PtCl}_{2}(\mathrm{DACH})$ and $\mathrm{PtBr}_{2}(\mathrm{DACH})$ (tested at their respective $\mathrm{IC}_{50} \mathrm{~S}$ ) produce on $\mathrm{HCT}-116$ cells, determining the distribution of the cells in the various phases of the cell cycle. These effects were measured in the absence or in the presence of the four compounds tested at their respective $\mathrm{IC}_{50}$ s. Preliminary results evidenced that as already reported for cisplatin, oxaliplatin and its iodido analog, ${ }^{5 a} \mathrm{PtCl}_{2}(\mathrm{DACH})$ and $\mathrm{PtBr}_{2}(\mathrm{DACH})$ caused a variation of cell cycle distribution of HCT-116 cells (Table 4 and Figure 6), with a block in G2/M phase. The same effect has been found also in HCT-8 cells (Figure 7 and Supplementary Table 1). 


\begin{tabular}{llll}
\cline { 2 - 4 } & G0/G1 (\%) & S (\%) & G2/M( \%) \\
\hline Control & $31.8 \pm 0.6$ & $31.2 \pm 0.9$ & $37.02 \pm 1.4$ \\
$\mathrm{PtCl}_{2}$ (DACH) & $20.2 \pm 2.7$ & $29.5 \pm 6.1$ & $50.2 \pm 6.1$ \\
$\mathrm{PtBr}_{2}$ (DACH) & $23.1 \pm 3.4$ & $20.4 \pm 2.4$ & $56.6 \pm 4.1$
\end{tabular}

Table 4. Cell cycle distribution of HCT-116 cells after 24 hours of treatment with $\mathrm{PtCl}_{2}(\mathrm{DACH})$ and $\mathrm{PtBr}_{2}(\mathrm{DACH})$ at the $\mathrm{IC}_{50}$ values shown in Table 3. Data are means \pm sem of four independent experiments, and are expressed as percentage of cells in each phase of the cell cycle, determined by flow cytometry after staining the cells with propidium iodide (PI).

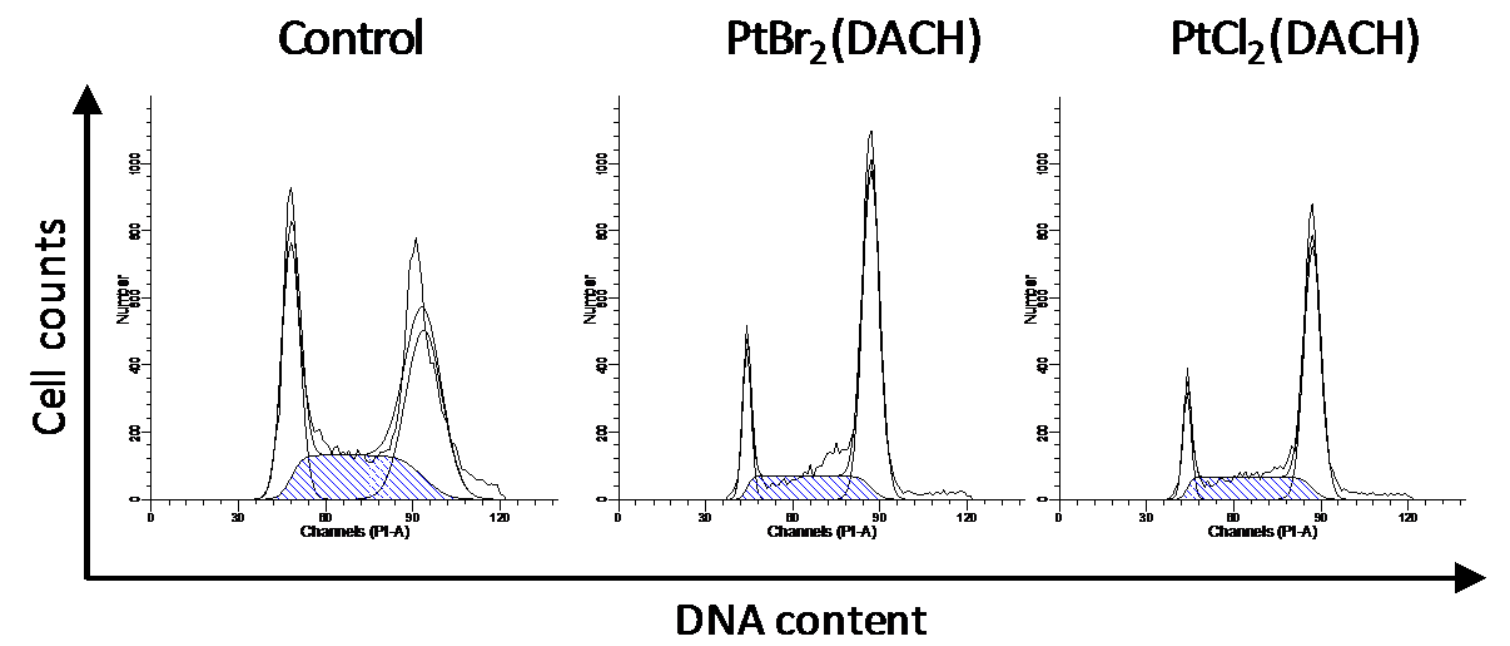

Figure 6. Cell cycle distribution of HCT-116 cells after 24 hours of treatment with $\mathrm{PtBr}_{2}(\mathrm{DACH})$ and $\mathrm{PtCl}_{2}(\mathrm{DACH})$ at the $\mathrm{IC}_{50}$ values. Representative histograms of data reported in Table 4.

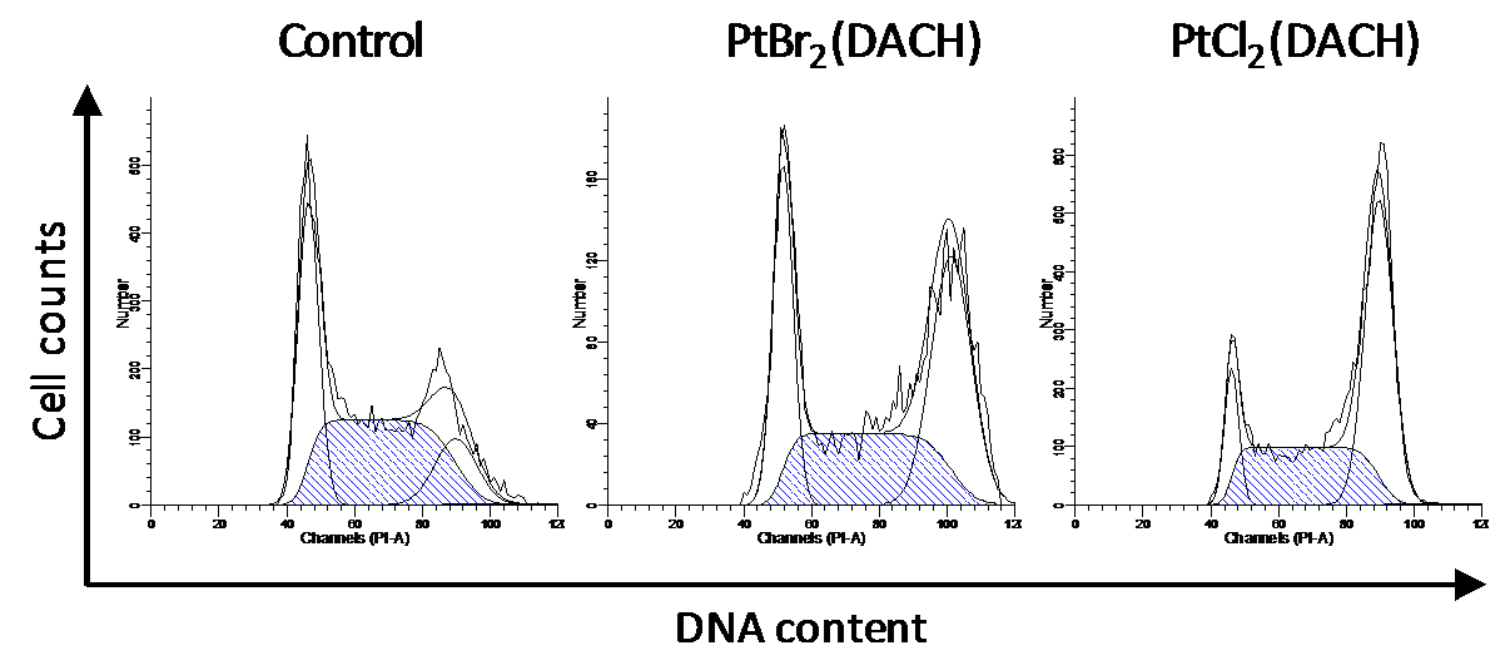

Figure 7. Cell cycle distribution of HCT-8 cells after 24 hours of treatment with $\mathrm{PtBr}_{2}(\mathrm{DACH})$ and $\mathrm{PtCl}_{2}(\mathrm{DACH})$ at the $\mathrm{IC}_{50}$ values. Representative histograms of data reported in Supplementary Table 1. 


\section{Conclusion}

Colorectal cancer is a global health problem being the fourth most common cause of death due to cancer worldwide. Oxaliplatin plays a key role in current CRC treatment but shows serious drawbacks, such as a high systemic toxicity and the frequent insurgence of Pt resistance.

This work continues a research line started a few years ago that is based on the idea that small modifications in the scaffold of established anticancer Pt drugs may lead to significant and hopefully positive changes in their pharmacological profile with appreciable effects in the overall spectrum of anticancer actions and in the ability to overcome Pt resistance in CRC. The exchange of halide ligands (e.g. replacement of chloride with iodide in cisplatin) represents indeed a small structural change with a relevant chemical and biological impact.

Specifically, we have prepared here two analogues of oxaliplatin, an established Pt drug, through incorporation of non-conventional halido ligands such as chloride and bromide. From the inspection of the solution behavior, we have observed a hydrolysis profiles similar to oxaliplatin, with a with a release of the halido ligand more faster for chloride than bromide or iodide.

At variance from oxaliplatin and in line with $\mathrm{PtI}_{2}(\mathrm{DACH})$, the selected compounds showed a scarce reactivity towards model proteins, while keeping affinity for a standard DNA oligo. These findings are considerably interesting, in fact, despite DNA is recognized as the main target for Pt-based anticancer agents, protein binding is nowadays considered a key aspect for the pharmacological profile. Interaction with aminoacidic residues of proteins may have a primary role in the pharmacokinetic and bioavailability of metal-based antineoplastic compounds. Also, the coordination of metal center to specific protein sites, may result in an inhibition and damage of enzymes, leading in turn to augmented side effects. ${ }^{18}$ Thus, the lack of reaction of the study compounds when reacted with model protein targets, and the concomitant conserved reactivity toward oligonucleotides may have important biological consequences.

Furthermore, we have shown that CRC cells that were treated with $\mathrm{PtCl}_{2}(\mathrm{DACH})$ and $\mathrm{PtBr}_{2}(\mathrm{DACH})$ showed at 24 hours a clear spike in the G2/M fraction; the cytotoxic properties versus CRC cell lines of the two study compounds were roughly comparable to those of oxaliplatin. This implies that the presence of the oxalate ligand is not crucial for the anticancer activity of oxaliplatin and that the latter may be replaced by halido ligands with nearly full retention of the cytotoxic properties. Results collected indicated that treatments with $\mathrm{PtCl}_{2}(\mathrm{DACH})$ and $\mathrm{PtBr}_{2}(\mathrm{DACH})$ affect growth of human CRC cells and induced cell cycle arrest suggesting an induction of cellular apoptosis.

Overall, a rather interesting picture emerges for this novel Pt drug that merits, in our opinion, a deeper and more extensive preclinical evaluation.

\section{Acknowledgments}

We gratefully acknowledge Beneficentia Stiftung, ITT (Istituto Toscano Tumori), Ente Cassa Risparmio Firenze (ECR), AIRC (IG-16049) COST Action CM1105 for financial support, CISM (University of Florence) for ESIMS spectra. T.M. thanks AIRC-FIRC (Fondazione Italiana per la Ricerca sul Cancro, 3-years Fellowship for Italy Project Code: 18044). C.G. and T. M acknowledge University of Pisa for PRA_2017_25 Grant. 


\section{References}

1. Ferlay J., Soerjomataram I., Ervik M., Dikshit R., Eser S., Mathers C., Rebelo M., Parkin D.M., Forman D., Bray F.: GLOBOCAN 2012 v 1.0, Cancer Incidence and Mortality Worldwide: IARC CancerBase No. 11. International Agency for Research on Cancer, Lyon (France) 2013.

2. Mehmood R. K., Oncol Rev. 2014, 23, 256.

3. Mayer R.J., J. Clin. Oncol., 2012, 30, 3325.

4. (a) Hochster H.S., Hart L.L., Ramanathan R.K., Childs B. H., Hainsworth J.D., Cohn A., Wong L., Fehrenbacher L., Abubakr Y., Wasif Saif M., Schwartzberg L., Hedrick E., J. Clin. Oncol., 2008, 26, 3523; (b) O'Dwyer P.J., Johnson S.W., Semin. Oncol., 2003, 30, 78.

5. (a)T. Marzo, S. Pillozzi, O. Hrabina, J. Kasparkova, V. Brabec, A. Arcangeli, G. Bartoli, M. Severi, A. Lunghi, F. Totti, C. Gabbiani, A. G. Quiroga, L. Messori, Dalton Trans., 2015, 44, 14896; (b) T. Marzo, G. Bartoli, C. Gabbiani, G. Pescitelli, M. Severi, S. Pillozzi, E. Michelucci, B. Fiorini, A. Arcangeli, A.G. Quiroga, L. Messori, Biometals, 2016, 29, 535.

6. Cirri, S. Pillozzi, C. Gabbiani, J. Tricomi, G. Bartoli, M. Stefanini, E. Michelucci, A. Arcangeli, L. Messori, T. Marzo, Dalton Trans 2017, 46, 3311-3317.

7 (a) Maixner, J., Pažout, R., Nováková, I., Holakovská, J., \& Kačer, P. Powder Diffraction, 2012, 27, 200; (b) Kidani Y, Inagaki K, Tsukagoshi S., GANN.,. 1976, 67, 921; (c) Kidani Y, Inagaki K, Saito R., J Clin Hematol Oncol, 1977, 7, 197; (d) Speer et al, J Clin Hematol Oncol, 1978, 8, 44;(e) Leh FKV, Wolf W, J Pharm Sci, 1976, 65, 315;

8 (a) Kidani, Yoshinori (2-1, Mataho-cho, Nishi-ku, Nagoya-shi, Aichi-ken, JP), Noji, Masahide (Nagoya, JP), 1981, Platinum complex, United States, patent n. 4256652; (b) Dhara, S. C. Ind. J. Chem. 1970, 8, 193.

9. Pažout R., Houskova J., Dušek M., Maixner J., Kačer P., Struct.Chem., 2011, 22, 1325.

10. Baker M. V., Barnard P. J., Berners-Price S. J., Brayshaw S. K., Hickey J. L., Skelton B. W., White A. H., Dalton Trans., 2006, 3708.

11 Gao W.G, Pu S.P., Liu W.P., Liu Z.D., Yang Y.K., Yao Xue Xue Bao, 2003, 38, 223.

12 Chowdhury S.K., Katta V., Beavis R.C., Chait B.T., J. Am. Soc. Mass Spectrom. 1990, 1, 382.

13. Messori L., Marzo T., Merlino A., J. Inorg. Biochem., 2015, 153, 136.

14. Messori L., Marzo T., Merlino A., Chem. Commun., 2014, 50, 8360.

15 Reedijk J. Proc. Natl. Acad. Sci. U S A. 2003, 100, 3611.

16 Jamieson, E. R.; Lippard, S. J. Chem. Rev. 1999, 99, 2467.

17 Mowaka S., Ziehe M., Mohamed D., Hochkirch U., Thomale J., Linscheid M.W., J. Mass Spectrom., 2012, 47, 1282.

18 Casini A., Reedijk J., Chem. Sci., 2012,3, 3135. 